\title{
Ligustrum lucidum Ait. fruit extract induces apoptosis and cell senescence in human hepatocellular carcinoma cells through upregulation of $\mathbf{p 2 1}$
}

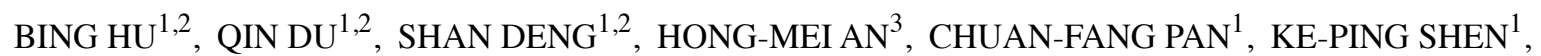 \\ LING XU ${ }^{1,2}$, MENG-MENG WEI ${ }^{1,2}$ and SHUANG-SHUANG WANG ${ }^{1,2}$ \\ ${ }^{1}$ Department of Oncology and ${ }^{2}$ Institute of Traditional Chinese Medicine in Oncology, Longhua Hospital, \\ Shanghai University of Traditional Chinese Medicine, Shanghai 202032; ${ }^{3}$ Department of Science and Technology, \\ Longhua Hospital, Shanghai University of Traditional Chinese Medicine, Shanghai 200032, P.R. China
}

Received April 23, 2014; Accepted June 24, 2014

DOI: $10.3892 /$ or.2014.3312

\begin{abstract}
Nü-zhen-zi, the fruit of Ligustrum lucidum Ait., is one of the most frequently used liver Yin tonifying Chinese herbs for the treatment of liver cancer. However, the effect of Ligustrum lucidum fruit on hepatocarcinoma cells remains unknown. In the present study, we evaluated the effects of a Ligustrum lucidum fruit extract (LLFE) on human hepatocellular carcinoma Bel-7402 cells. The results showed that LLFE inhibited the proliferation of the Bel-7402 cells in a dose- and time-dependent manner. LLFE induced apoptosis in Bel-7402 cells accompanied by activation of caspase-3, -8 and -9 . LLFE-induced apoptosis was completely abrogated by a pan caspase inhibitor, Z-VAD-FMK. LLFE treatment also caused a large and flat morphologic cellular change, positive SA- $\beta$-gal staining, and $G_{0} / G_{1}$ phase cell cycle arrest in the Bel-7402 cells, accompanied by upregulation of $\mathrm{p} 21$ and downregulation of RB phosphorylation. Specific knockdown of p21 expression by RNA interference partially abrogated LLFE-induced apoptosis, and significantly abrogated LLFE-induced cell senescence. These observations suggest that Nü-zhen-zi is a potential anticancer herb and support the traditional use of Nü-zhen-zi for hepatocarcinoma treatment.
\end{abstract}

\section{Introduction}

Liver cancer remains the fifth most common cancer in men and the seventh in women worldwide (1). The curative effect of current treatment for liver cancer is less than satisfactory. There is a great need to develop new approaches for liver cancer treatment. In China, Traditional Chinese Medicine (TCM)

Correspondence to: Dr Bing Hu, Department of Oncology, Longhua Hospital, Shanghai University of Traditional Chinese Medicine, Shanghai 202032, P.R. China

E-mail: beearhu@hotmail.com

Key words: hepatocellular carcinoma, Ligustrum lucidum fruit, apoptosis, cell senescence, p21 has long been used for liver cancer treatment, and has been confirmed to effectively control cancer progression, improve the quality of life, and prolong survival times to some extent in liver cancer patients (2-5). Based on different syndrome patterns, TCM therapeutic principles, such as invigorating spleen and regulating Qi, clearing heat-dampness, dissipating stasis, softening hardness, or tonifying liver and kidney can be used to treat cancer (5-8).

The fruit of Ligustrum lucidum Ait. (Nü-zhen-zi in Chinese) is one of the most frequently used liver/kidney Yin tonifying herbs in liver cancer patients for clinical syndrome amelioration (9). As a tonic Chinese herb, Ligustrum lucidum fruit has been confirmed to be effective in improving chemotherapy-induced myelosuppression, alopecia and immunosuppression (10-12). Ligustrum lucidum fruit has also been used to enhance the therapeutic effects of chemotherapy in TCM clinical practice. Ligustrum lucidum fruit has been demonstrated to display antiproliferative potential against lung and pancreatic carcinoma, breast and prostate adenocarcinoma, glioma and colorectal carcinoma (13-15). However, the effect of Ligustrum lucidum fruit on liver cancer cells remains unknown.

The present study aimed to evaluate the effect of an aqueous extract of Ligustrum lucidum fruit on hepatocarcinoma cells. We observed that Ligustrum lucidum fruit extract (LLFE) induced apoptosis in human hepatocellular carcinoma Bel-7402 cells through activation of caspases. LLFE also induced cell senescence accompanied by upregulation of p21 and downregulation of RB phosphorylation. In addition, silencing of p21 by RNA interference partially abrogated LLFE-induced apoptosis, and significantly abrogated LLFEinduced cell senescence.

\section{Materials and methods}

Chemicals and reagents. The Cell Counting Kit-8 (CCK-8) was obtained from Dojindo (Kumamoto, Japan). Colorimetric CaspACE $^{\mathrm{TM}}$ Assay System was the product of Promega (Madison, WI, USA). Z-VAD-FMK, Caspase-8 and Caspase-9 Colorimetric Assay kits were purchased from R\&D Systems 
(Minneapolis, MN, USA). Antibodies against p53, p16, p21, $\mathrm{RB}, \mathrm{pRB}$ and $\beta$-actin, and the Senescence $\beta$-Gal staining kit were the products of Cell Signaling Technology (Danvers, MA, USA). Small interfering RNA (siRNA) against p21 and control siRNA were procured from Santa Cruz Biotechnology (Santa Cruz, CA, USA). Lipofectamine ${ }^{\mathrm{TM}} 2000$ was from Invitrogen (Carlsbad, CA, USA).

Extraction of Ligustrum lucidum fruit. An aqueous extract of Ligustrum lucidum fruit was prepared as a lyophilizeddry powder as previously described $(16,17)$. Authentic Ligustrum lucidum fruit herb material was obtained from Longhua Hospital. Ligustrum lucidum fruit was soaked for $1 \mathrm{~h}$, and decocted twice with an 8-fold volume of boiling distilled water for $2 \mathrm{~h}$. The decoction was filtered and centrifuged twice at $12,000 \mathrm{rpm}$ for $30 \mathrm{~min}$ to remove the insoluble ingredients. The supernatants were mixed with an equal volume of ethanol and kept at $4{ }^{\circ} \mathrm{C}$ overnight, and centrifuged at $12,000 \mathrm{rpm}$ for $30 \mathrm{~min}$ to remove the insoluble ingredients. The resultant supernatants were lyophilized, weighed, dissolved in RPMI1640 medium and adjusted to a concentration of $400 \mathrm{mg} / \mathrm{ml}$, and were sequentially passed through 0.45 - and $0.22-\mu \mathrm{m}$ filters and sterilized.

Cell culture. Human hepatocellular carcinoma Bel-7402 cells and human hepatocyte HL-7702 cells were obtained from the Cell Bank of the Type Culture Collection of the Chinese Academy of Sciences. Bel-7402 and HL-7702 cells were grown in RPMI-1640 medium with 10\% FBS and 1\% pen-strep, and maintained at $37^{\circ} \mathrm{C}$ in a humidified incubator with a $5 \% \mathrm{CO}_{2}$ atmosphere.

Cell proliferation assay. Cells in logarithmic growth phase were seeded into a 96 -well plate $\left(4 \times 10^{3}\right.$ cells/well) and allowed to attach for $24 \mathrm{~h}$ before treatment. The cells were exposed to various doses of LLFE for $72 \mathrm{~h}$, and cell viability was evaluated every $24 \mathrm{~h}$ by using the CCK- 8 colorimetric assay according to the manufacturer's instructions. The cell survival rate was calculated as follows: Cell survival rate $(\%)=$ experimental OD value/control OD value x $100 \%$.

Flow cytometric analysis. LLFE-treated Bel-7402 cells were collected, stained with Annexin V-FITC and PI as recommended by the manufacturer, and detected using a FACSCalibur flow cytometer (Becton-Dickinson). For cell cycle analysis, LLFE-treated Bel-7402 cells were stained with PI $(50 \mu \mathrm{g} / \mathrm{ml})$ and analyzed using a FACSCalibur flow cytometer.

Caspase activity assay. After treatment with different concentrations of LLFE, caspase- $3,-8$ and -9 activities were measured by the cleavage of the specific chromogenic substrate according to the manufacturer's instructions. For caspase inhibition, cells pretreated with Z-VAD-FMK $(50 \mu \mathrm{mol} / 1,2 \mathrm{~h})$ were incubated with LLFE for another $72 \mathrm{~h}$.

Senescence-activated $\beta$-galactosidase staining. Bel-7402 cells $\left(3 \times 10^{4}\right)$ were plated in $35-\mathrm{mm}$-diameter plates and treated with different doses of LLFE for 5 days. Senescence-activated expression of $\beta$-galactosidase activity (18) was detected by the
Senescence $\beta$-Gal staining kit according to the manufacturer's protocol, and observed under a microscope.

Western blotting. Western blot analyses were performed as previously described $(16,17)$. Briefly, collected cells were lysed and subjected to 8-12\% SDS-PAGE gel, and transferred onto a nitrocellulose membrane (Amersham Biosciences, Buckinghamshire, UK). The transferred membranes were blocked with 5\% non-fat milk, washed, and probed with the indicated antibodies. Blots were then washed and incubated with IRDye 700- and IRDye 800-conjugated secondary antibodies (Rockland Immunochemicals, Gilbertsville, PA, USA), and visualized in the Odyssey Infrared Imaging System (LI-COR Biosciences, Lincoln, NE, USA).

siRNA treatment. For siRNA transfection, Bel-7402 cells were cultured on a 6-well plate to $60 \%$ confluency, and 80 pmol of specific or non-specific control siRNA was introduced into the cells using Lipofectamine ${ }^{\mathrm{TM}} 2000$ according to the manufacturer's recommendations. After $24 \mathrm{~h}$ of transfection, cells were treated with $200 \mu \mathrm{g} / \mathrm{ml}$ of LLFE or the same volume of RPMI-1640, and harvested for apoptosis assay or senescence $\beta$-Gal staining.

Statistical analyses. Results are expressed as means \pm standard deviation of at least two independent experiments, each conducted in triplicate. Differences between the control and LLFE treatment were analyzed by one-way ANOVA. Differences were considered to indicate a statistically significant result at $\mathrm{P}<0.05$.

\section{Results}

LLFE inhibits the proliferation of Bel-7402 cells. The effect of LLFE on the proliferation of Bel-7402 cells was detected by CCK-8 assay. At final concentrations of 50-800 $\mu \mathrm{g} / \mathrm{ml}$, LLFE significantly inhibited the proliferation of Bel-7402 cells in a dose- and time-dependent manner (Fig. 1A) $(\mathrm{P}<0.05)$. In contrast, LLFE had no significant effect on the proliferation of human normal hepatocyte HL-7702 cells even at concentrations that were highly toxic to the Bel-7402 cells (Fig. 1B). These observations were consistent with a previous report that aqueous extracts of Ligustrum lucidum are inactive on normal human mammary epithelial cells (13).

LLFE induces the apoptosis of Bel-7402 cells. Apoptosis, an evolutionarily conserved cell suicide process elicited by physiological, pathological or pharmacological stimuli, has been recognized as a major anticancer treatment response $(19,20)$. Thus, we determined the effects of LLFE on the apoptosis of Bel-7402 cells. As shown in Fig. 2, treatment with $100-400 \mu \mathrm{g} / \mathrm{ml}$ of LLFE for $72 \mathrm{~h}$ induced significant apoptosis in the Bel-7402 cells in a dose-dependent manner $(\mathrm{P}<0.01)$.

LLFE activates caspases in Bel-7402 cells. To determine whether caspases contribute to the LLFE-induced apoptosis of Bel-7402 cells, activities of caspases were measured by the cleavage of the specific substrate. Caspase activity assays showed that LLFE activated caspase- $3,-8$ and -9 in the Bel-7402 cells in a dose-dependent manner (Fig. 3A-C) $(\mathrm{P}<0.01)$. In addi- 

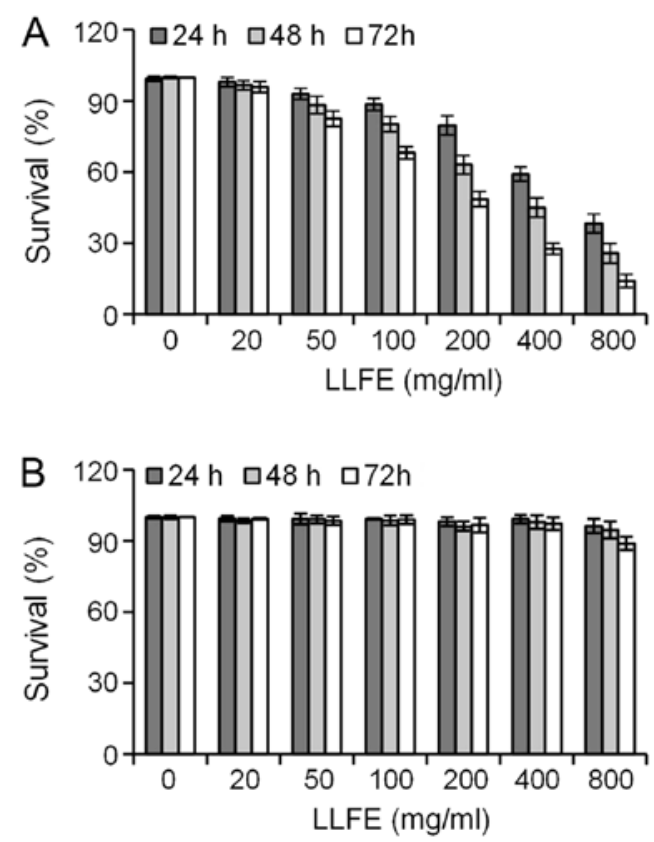

Figure 1. Effects of LLFE on the proliferation of Bel-7402 and HL-7702 cells. (A) Human hepatocellular carcinoma Bel-7402 cells and (B) human normal hepatocyte HL-7702 cells were treated with different concentrations of LLFE for $72 \mathrm{~h}$, and cell viability was evaluated every $24 \mathrm{~h}$ by CCK- 8 assay. Data shown are representative of three independent experiments. LLFE, Ligustrum lucidum fruit extract; CCK-8, Cell Counting Kit-8.

tion, LLFE-induced apoptosis of Bel-7402 cells was completely abrogated by the pan-caspase inhibitor Z-VAD-FMK (Fig. 3D) $(\mathrm{P}<0.01)$, suggesting that LLFE-induced apoptosis is associated with the caspase cascade.

LLFE induces cell senescence in Bel-7402 cells. Upon treatment with low doses of LLFE, the Bel-7402 cells gradually
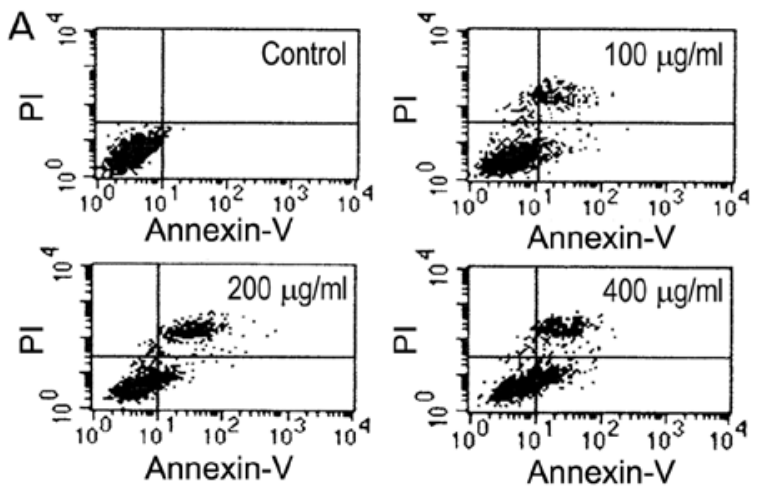

B

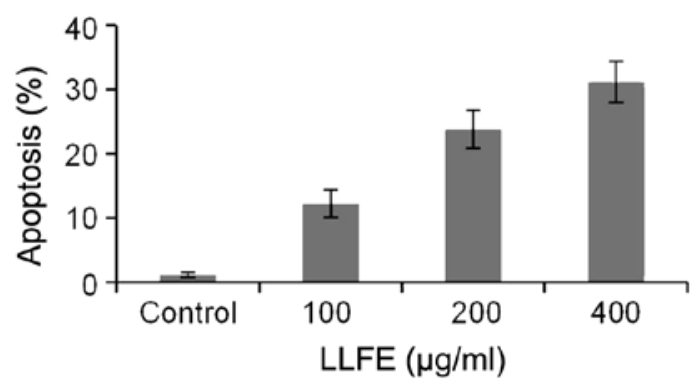

Figure 2. LLFE induces apoptosis. (A) Bel-7402 cells were treated with the indicated doses of LLFE for $72 \mathrm{~h}$. Apoptotic cells were quantified by Annexin V/PI staining and flow cytometric analysis, and (B) expressed as the mean percentage \pm SD. LLFE, Ligustrum lucidum fruit extract.

exhibited a large and flattened morphology, indicative of cell senescence (Fig. 4). Thus, we further performed senescenceactivated $\beta$-galactosidase (SA- $\beta$-gal) staining. As shown in Fig. 4, LLFE treatment resulted in a higher percentage of cells with SA- $\beta$-gal-positive staining, compared with the controls $(\mathrm{P}<0.01)$. In addition, flow cytometric analysis revealed that the cell cycle of LLFE-treated Bel-7402 cells was

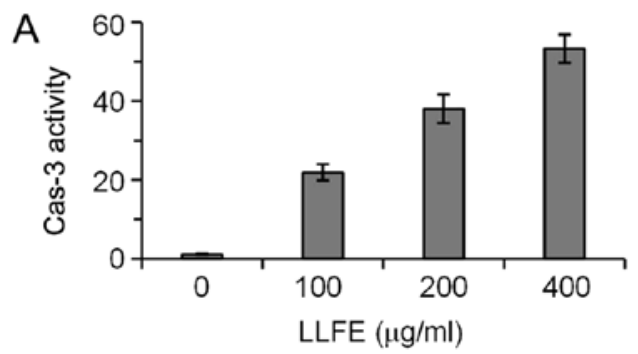

B
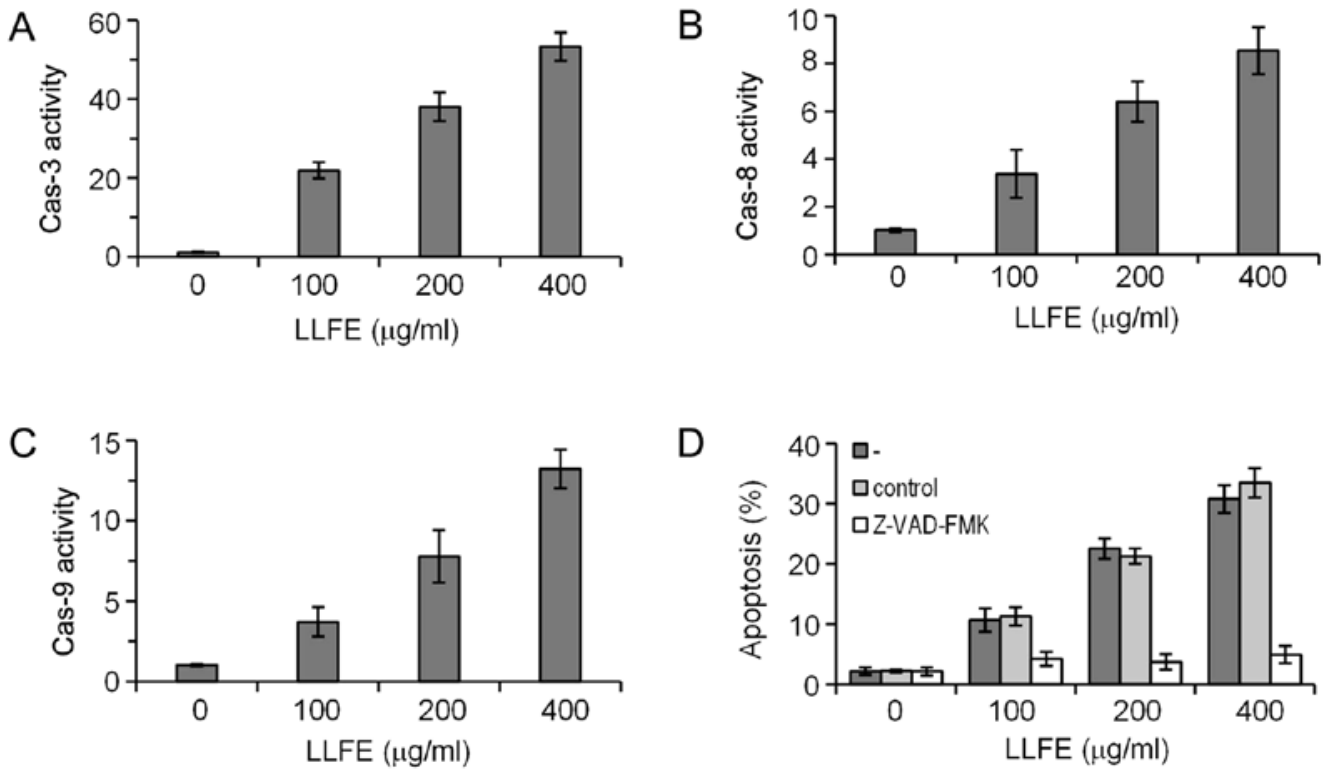

Figure 3. LLFE activates caspase activity. Bel-7402 cells were treated with 100-400 $\mu \mathrm{g} / \mathrm{ml}$ of LLFE for $72 \mathrm{~h}$. (A) Caspase-3, (B) caspase-8 and (C) caspase-9 activities were measured by the cleavage of the specific chromogenic substrate. (D) After pretreatment with Z-VAD-FMK (50 $\mu$ mol/l) for $2 \mathrm{~h}$, Bel-7402 cells were exposed to 100-400 $\mu \mathrm{g} / \mathrm{ml}$ of LLFE for $72 \mathrm{~h}$, and subjected to apoptosis detection by flow cytometric analysis. LLFE, Ligustrum lucidum fruit extract. 
A

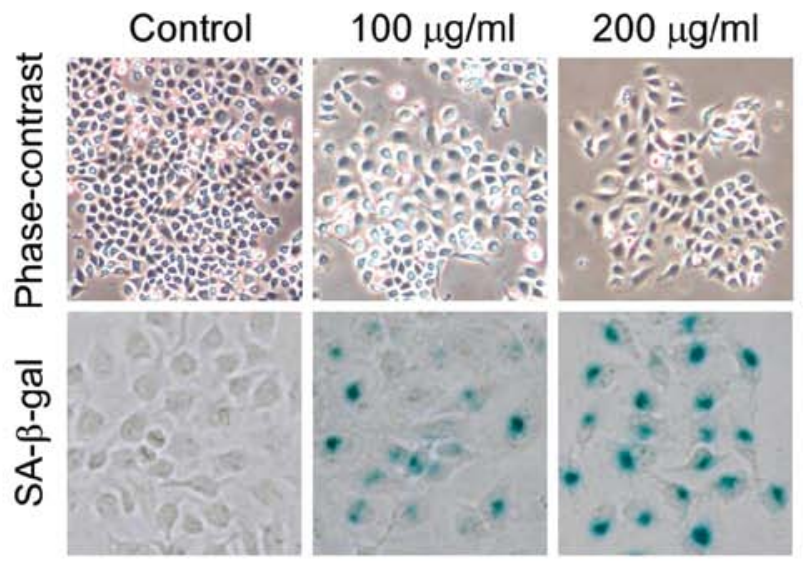

B

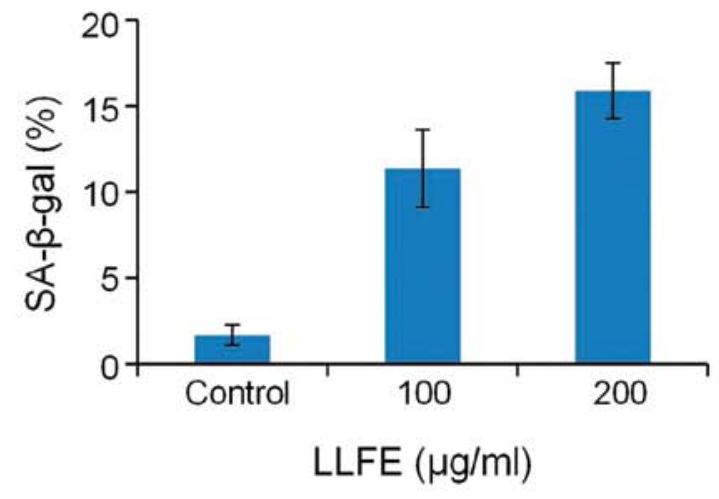

Figure 4. LLFE activates SA- $\beta$-gal. (A) Bel-7402 cells were treated with 100 and $200 \mu \mathrm{g} / \mathrm{ml}$ LLFE for 5 days. Cell morphological changes were observed under a microscope (upper panels, $\mathrm{x} 400$ ), and cells were subjected to SA- $\beta$-gal staining and observed under a microscope (lower panels, $\mathrm{x} 1,000$ ). (B) Percentage \pm SD of SA- $\beta$-gal-positive cells from a representative experiment. LLFE, Ligustrum lucidum fruit extract.
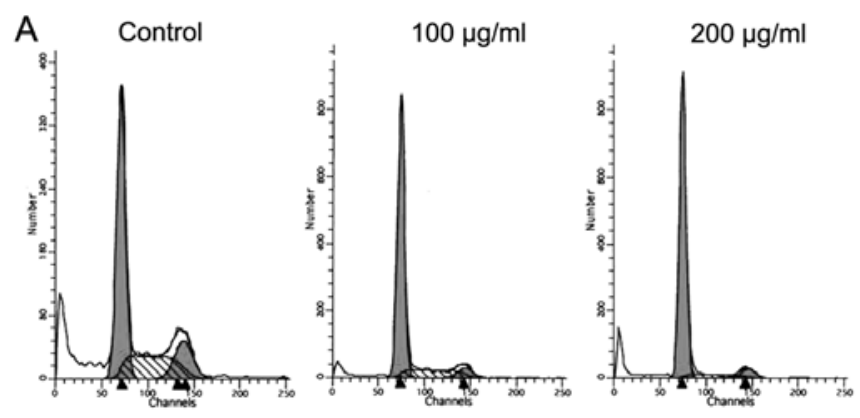

B

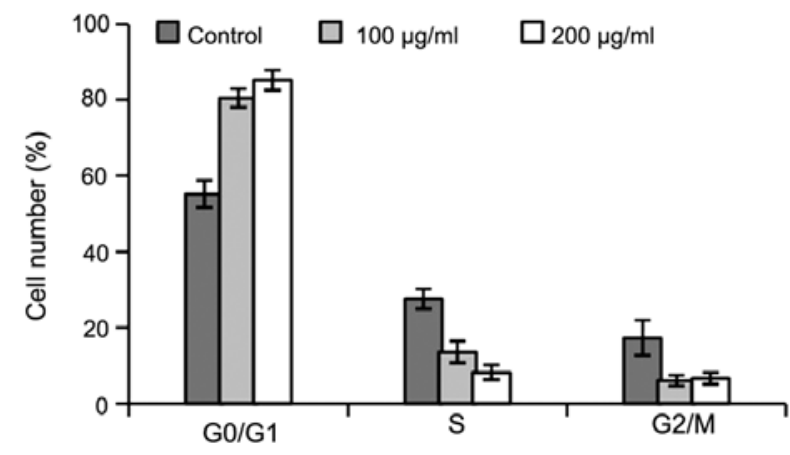

Figure 5. LLFE induces cell cycle arrest. Bel-7402 cells were treated with 100 and $200 \mu \mathrm{g} / \mathrm{ml}$ LLFE for 5 days. (A) Cell cycle distribution of LLFE-treated Bel-7402 cells was analysis by flow cytometric analysis, and (B) expressed as means \pm SD. LLFE, Ligustrum lucidum fruit extract.

arrested in the $\mathrm{G}_{0} / \mathrm{G}_{1}$ phase (Fig. 5) $(\mathrm{P}<0.01)$. These observations suggest that LLFE induces senescence in Bel-7402 cells.

Effects of LLFE on the expression of senescence regulatory genes. It has been reported that cell senescence is regulated by the CDKN1a (p21 $\left.1^{\text {WAF-1/Cip1 }}\right) / \mathrm{pRB}$ or the CDKN2a $\left(\mathrm{p} 16^{\mathrm{INK} 4 \mathrm{~A}}\right) / \mathrm{pRB}$ signaling pathway $(21,22)$. We examined the effects of LLFE on the expression of senescence regulatory genes in the Bel-7402 cells by western blotting. As shown in Fig. 6, treatment with low doses of LLFE caused an upregulation in the p21 expression, and downregulation of RB phosphorylation. However, expression of p53 and p16 was not detected in the Bel-7402 cells.

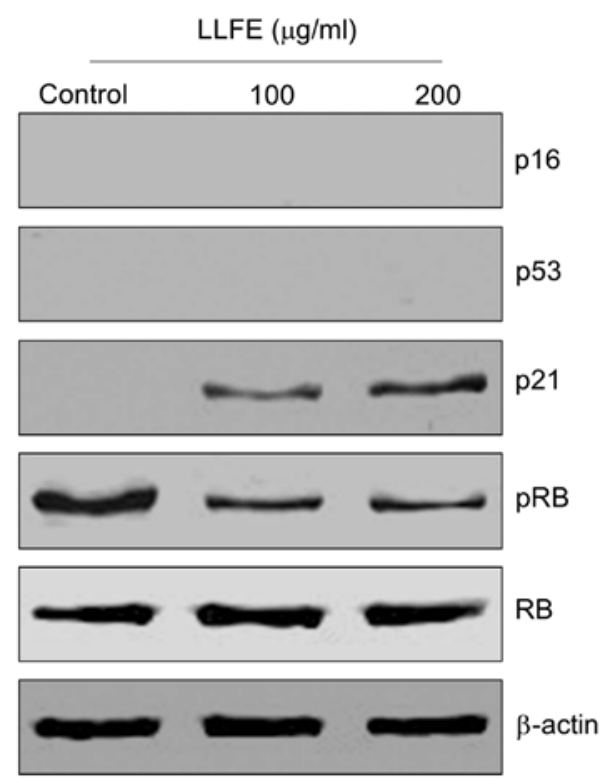

Figure 6. Effects of LLFE on expression of cell senescence regulatory genes. Bel-7402 cells were collected after 5 days of treatment with LLFE (100 and $200 \mu \mathrm{g} / \mathrm{ml}$ ), and subjected to western blot analyses using antibodies against p16, p53, p21, RB and pRB. $\beta$-actin was used as a loading control. LLFE, Ligustrum lucidum fruit extract.

Role of p21 in LLFE-induced apoptosis and cell senescence. Since p21 expression is upregulated by LLFE, we further determined the role of $\mathrm{p} 21$ in LLFE-induced apoptosis and cell senescence. As shown in Fig. 7, the expression of p21 was significantly inhibited by specific siRNA. Specific knockdown of p21 expression partially abrogated LLFE-induced apoptosis (Fig. 7A), and significantly abrogated LLFE-induced cell senescence (Fig. 7B). These observations suggest that p21 may contribute to LLFE-induced apoptosis and cell senescence.

\section{Discussion}

The present study demonstrated that LLFE inhibited proliferation in a dose- and time-dependent manner, and induced apoptosis in Bel-7402 cells. The initiation and execution of 
A
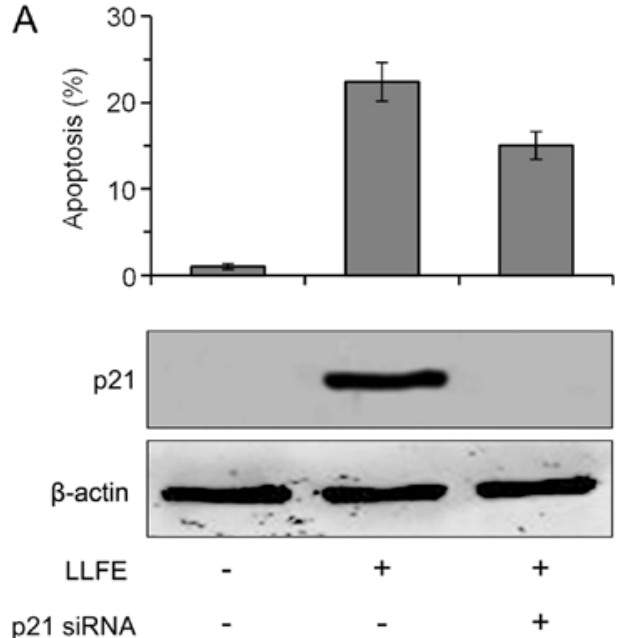

B
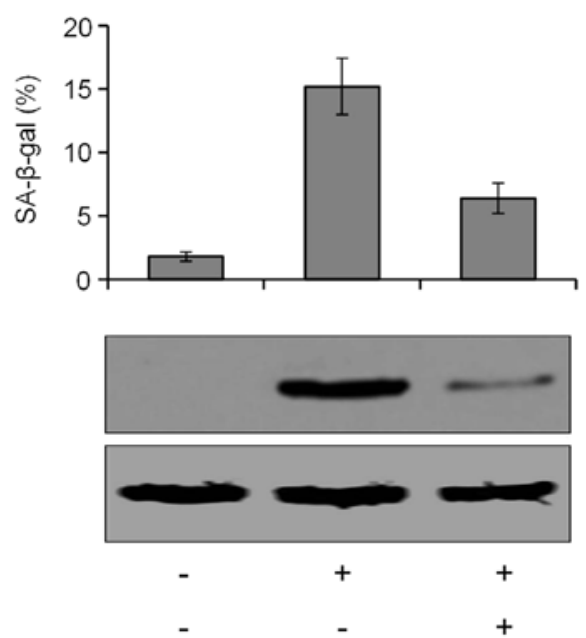

Figure 7. Role of p21 in LLFE-induced apoptosis and cell senescence. After 24 h of transfection with p21 siRNA or control siRNA, Bel-7402 cells were treated with $200 \mu \mathrm{g} / \mathrm{ml}$ of LLFE for 3 or 5 days, and subjected to western blot analyses and (A) apoptosis detection, and (B) SA- $\beta$-gal staining. LLFE, Ligustrum lucidum fruit extract.

apoptosis are dependent on the activation of the extrinsic and/ or intrinsic death pathways $(19,20,23)$. The extrinsic or death receptor pathways are associated with the oligomerization of cell-surface death receptors by their ligands, resulting in recruitment and activation of caspase- 8 followed by activation of executioner caspase-3. On the other hand, intrinsic or the mitochondrial pathway involves signals to the mitochondria that lead to the release of cytochrome $c$ and Apaf-1, forming an apoptosome that activates the initiating protease caspase-9, which in turn activates caspase-3, causing the cell to undergo apoptosis. The present study showed that LLFE activates caspase-8, -9 and -3 , and LLFE-induced apoptosis was blocked by a caspase inhibitor. These observations indicate that LLFEinduced apoptosis in Bel-7402 cells is through the extrinsic and intrinsic pathways.

In addition to apoptosis, cell senescence plays an important role in suppressing tumorigenesis, and may contribute to the outcome of cancer therapy (19,24-26). Cell senescence is a state of stable irreversible cell cycle arrest provoked by a variety of stimuli. Senescent cells maintain some metabolic activity, but can no longer proliferate, even stimulated with mitogens. Cell senescence is usually characterized by large and flattened morphology, an increase in intracellular granules, elevated SA- $\beta$-gal activity, and cell cycle arrest $(18,24)$. It has been reported that chemotherapeutic agents such as cisplatin, doxorubicin, SN-38, and camptothecin can inhibit cancer cell growth via cell senescence (26-29). In the present study, we observed that a low dose of LLFE treatment caused large and flat morphologic cellular changes, positive SA- $\beta$-gal staining, and $G_{0} / G_{1}$ phase cell cycle arrest, suggesting that LLFE treatment induces cell senescence in Bel-7402 cells.

Cell senescence is closely related to the activation of the CDKN1a (p21 $1^{\text {WAF-1/Cipl }) / p R B ~ o r ~ t h e ~ C D K N 2 a ~}\left(\mathrm{p} 16^{\text {INK4A }}\right) / \mathrm{pRB}$ signaling pathway $(21,22)$. p21, an important cell cycle regulator, can inhibit a variety of cyclin/CDK complexes and induce the hypophosphorylation or dephosphorylation of protein $\mathrm{Rb}$. Hypophosphorylated Rb binds to E2F and prevents it from activating target genes that are essential in the cell cycle, usually leading to cell cycle arrest. Overexpression of p21 may induce a senescence-like state in cancer cells (30). In addition, p21 also contributes to drug-induced apoptosis in cancer cells $(31,32)$. Expression of p21 in cancer cells may be dependent or independent of p53 (33-36). The present study showed that LLFE treatment resulted in cell senescence accompanied by upregulation of $\mathrm{p} 21$ and downregulation of $\mathrm{RB}$ phosphorylation, suggesting that $\mathrm{p} 21 / \mathrm{RB}$ may contribute to LLFE-induced cell senescence. Since p53 was not expressed in the Bel-7402 cells, p21 induced by LLFE may be independent of p53. Further observations revealed that knockdown of p21 expression significantly abrogated LLFE-induced cell senescence, suggesting that the effects of LLFE on cell senescence may depend on p21. LLFE-induced apoptosis was partially abrogated by $\mathrm{p} 21$ silencing suggesting that the effects of LLFE on apoptosis may partially involve $\mathrm{p} 21$.

In summary, the present study demonstrated that LLFE activates caspases to induce apoptosis in human hepatocellular carcinoma Bel-7402 cells with the participation of p21. LLFE also induced cell senescence in Bel-7402 cells, which may correlate with upregulation of p21 and downregulation of RB phosphorylation. These observations suggest that Nü-zhen-zi is a potential anticancer herb and support the traditional use of Nü-zhen-zi for liver cancer treatment. Nevertheless, further studies are needed to determine the upstream signal transduction of p21 upregulation, and to address which chemical(s) are responsible for the LLFE-induced anticancer effects.

\section{Acknowledgements}

This study was partially supported by the National Natural Science Foundation of China (81273726), the Three-year Action Program of Shanghai Municipality for Traditional Chinese Medicine (ZYSNXD-CC-ZDYJ017), the Xing-Lin Scholars Program, the Long-Yi Scholars and Research Team Program from the State Clinical Research Center of TCM in Longhua Hospital (LYTD-04), and the Shanghai Shen Kang Platform Grant (SHDC12007206). We also thank the Shanghai Key Laboratory of Tissue Engineering for technical assistance. 


\section{References}

1. Jemal A, Bray F, Center MM, Ferlay J, Ward E and Forman D: Global cancer statistics. CA Cancer J Clin 61: 69-90, 2011.

2. Yu Y, Lang Q, Chen Z, Li B, Yu C, Zhu D, Zhai X and Ling C: The efficacy for unresectable hepatocellular carcinoma may be improved by transcatheter arterial chemoembolization in combination with a traditional Chinese herbal medicine formula: a retrospective study. Cancer 115: 5132-5138, 2009.

3. Meng MB, Cui YL, Guan YS, Ying Z, Zheng MH, Yuan CK and Zhang RM: Traditional Chinese medicine plus transcatheter arterial chemoembolization for unresectable hepatocellular carcinoma. J Altern Complement Med 14: 1027-1042, 2008.

4. Shu X, McCulloch M, Xiao H, Broffman M and Gao J: Chinese herbal medicine and chemotherapy in the treatment of hepatocellular carcinoma: a meta-analysis of randomized controlled trials. Integr Cancer Ther 4: 219-229, 2005.

5. Du Q, Hu B, Shen KP and An HM: Pathogenesis and treatment law of Traditional Chinese Medicine in hepatocarcinoma. World J Integr Tradit West Med 5: 814-817, 2010 (In Chinese).

6. Yan JG and Yao SK: The study of TCM syndrome differentiation and treatment in liver cancer. Chin J Integr Tradit West Med Liver Dis 20: 189-190, 2010 (In Chinese).

7. Pan MQ and Tian H: Employ the methods of invigorating spleen and regulating Qi, clearing toxic heat, dissipating stasis and softening hardness to treat primary hepatic cancer. J Tradit Chinese Med 34: 239-240, 1993 (In Chinese).

8. Li YL and Zhang SP: The effects of invigorating spleen and regulating Qi in patients with primary hepatic cancer: an analysis of 127 cases. Tianjin Tradit Chinese Med 17: 12-13, 2000 (In Chinese).

9. Liu Q, Zhang YB, Ma CH, Yue XQ and Ling CQ: Analysis of literature on therapeutic methods and medicines of traditional Chinese medicine for primary liver cancer. Zhong Xi Yi Jie He Xue Bao 3: 260-262, 2005 (In Chinese).

10. Bo X, Zhao XM, Liu HT, Ma WG and Li H: A study on 4 kinds of Chinese medicines reducing arrest of bone marrow by cyclophosphomidum. J Beijing Union Univ (Natural Science) 8: 58-61, 1994 (In Chinese).

11. Zhao YL and Fan WX: The effects of Nü-zhen-zi formula on chemotherapy induced alopecia. Acta Univ Med Nanjing (Natural Science) 24: 305-306, 2004 (In Chinese).

12. Wu XF, Han SY, Zhu LS, Bai J and Liu SM: The effects of Ligustrum lucidum Ait. fruits extract on cyclophosphomidum induced immunosuppression. J North China Coal Med Coll 10: 303-304, 2008 (In Chinese).

13. Shoemaker M, Hamilton B, Dairkee SH, Cohen I and Campbell MJ: In vitro anticancer activity of twelve Chinese medicinal herbs. Phytother Res 19: 649-651, 2005.

14. Jeong JC, Kim JW, Kwon CH, Kim TH and Kim YK: Fructus ligustri lucidi extracts induce human glioma cell death through regulation of Akt/mTOR pathway in vitro and reduce glioma tumor growth in U87MG xenograft mouse model. Phytother Res 25: 429-434, 2011.

15. Zhang JF, He ML, Qi Dong, Xie WD, Chen YC, Lin MC, Leung PC, Zhang YO and Kung HF: Aqueous extracts of Fructus Ligustri Lucidi enhance the sensitivity of human colorectal carcinoma DLD-1 cells to doxorubicin-induced apoptosis via Tbx3 suppression. Integr Cancer Ther 10: 85-91, 2011.

16. Hu B, An HM, Shen KP, Xu L, Du Q, Deng S and Wu Y: Modified Yi Guan Jian, a Chinese herbal formula, induces anoikis in Bel-7402 human hepatocarcinoma cells in vitro. Oncol Rep 26: 1465-1470, 2011.

17. $\mathrm{Hu} \mathrm{B}$, Shen KP, An HM, Wu Y and Du Q: Aqueous extract of Curcuma aromatica induces apoptosis and $\mathrm{G} 2 / \mathrm{M}$ arrest in human colon carcinoma LS-174-T cells independent of p53. Cancer Biother Radiopharm 26: 97-104, 2011.
18. Dimri GP, Lee X, Basile G, Acosta M, Scott G, Roskelley C, Medrano EE, Linskens M, Rubelj I, Pereira-Smith O, Peacocke M and Campisi J: A biomarker that identifies senescent human cells in culture and in aging skin in vivo. Proc Natl Acad Sci USA 92: 9363-9367, 1995.

19. Chiantore MV, Vannucchi S, Mangino G, Percario ZA, Affabris E, Fiorucci G and Romeo G: Senescence and cell death pathways and their role in cancer therapeutic outcome. Curr Med Chem 16: 287-300, 2009.

20. Brown JM and Attardi LD: The role of apoptosis in cancer development and treatment response. Nat Rev Cancer 5: 231-237, 2005.

21. Roninson IB: Tumor cell senescence in cancer treatment. Cancer Res 63: 2705-2715, 2003.

22. Dimri GP: What has senescence got to do with cancer? Cancer Cell 7: 505-512, 2005.

23. Meier P and Vousden KH: Lucifer's labyrinth - ten years of path finding in cell death. Mol Cell 28: 746-754, 2007.

24. Schmitt CA: Cellular senescence and cancer treatment. Biochim Biophys Acta 1775: 5-20, 2007.

25. Gewirtz DA, Holt SE and Elmore LW: Accelerated senescence: an emerging role in tumor cell response to chemotherapy and radiation. Biochem Pharmacol 76: 947-957, 2008.

26. Nardella C, Clohessy JG, Alimonti A and Pandolfi PP: Pro-senescence therapy for cancer treatment. Nat Rev Cancer 11: 503-511, 2011.

27. Di X, Shiu RP, Newsham IF and Gewirtz DA: Apoptosis, autophagy, accelerated senescence and reactive oxygen in the response of human breast tumor cells to adriamycin. Biochem Pharmacol 77: 1139-1150, 2009.

28. te Poele RH, Okorokov AL, Jardine L, Cummings J and Joel SP: DNA damage is able to induce senescence in tumor cells in vitro and in vivo. Cancer Res 62: 1876-1883, 2002.

29. Han Z, Wei W, Dunaway S, Darnowski JW, Calabresi P, Sedivy J, Hendrickson EA, Balan KV, Pantazis P and Wyche JH: Role of p21 in apoptosis and senescence of human colon cancer cells treated with camptothecin. J Biol Chem 277: 17154-17160, 2002.

30. Kagawa S, Fujiwara T, Kadowaki Y, Fukazawa T, Sok-Joo R, Roth JA and Tanaka N: Overexpression of the $p 21^{\text {sdil }}$ gene induces senescence-like state in human cancer cells: implication for senescence-directed molecular therapy for cancer. Cell Death Differ 6: 765-772, 1999.

31. Ahmad N, Adhami VM, Afaq F, Feyes DK and Mukhtar $\mathrm{H}$ : Resveratrol causes WAF-1/p21-mediated $\mathrm{G}_{1}$-phase arrest of cell cycle and induction of apoptosis in human epidermoid carcinoma A431 cells. Clin Cancer Res 7: 1466-1473, 2001.

32. Liu WK, Cheung FW, Liu BP, Li C, Ye W and Che CT: Involvement of p21 and FasL in induction of cell cycle arrest and apoptosis by neochamaejasmin $\mathrm{A}$ in human prostate $\mathrm{LNCaP}$ cancer cells. J Nat Prod 71: 842-846, 2008.

33. Thaler S, Hähnel PS, Schad A, Dammann R and Schuler M: RASSF1A mediates p21 Cip1/Waf1-dependent cell cycle arrest and senescence through modulation of the Raf-MEK-ERK pathway and inhibition of Akt. Cancer Res 69: 1748-1757, 2009.

34. Peng CC, Chen KC, Peng RY, Chyau CC, Su CH and Hsieh-Li HM: Antrodia camphorata extract induces replicative senescence in superficial TCC, and inhibits the absolute migration capability in invasive bladder carcinoma cells. J Ethnopharmacol 109: 93-103, 2007.

35. Wakoh T, Uekawa N, Terauchi K, Sugimoto M, Ishigami A, Shimada $J$ and Maruyama M: Implication of p53-dependent cellular senescence related gene, TARSH in tumor suppression. Biochem Biophys Res Commun 380: 807-812, 2009.

36. Lodygin D, Menssen A and Hermeking H: Induction of the Cdk inhibitor p21 by LY83583 inhibits tumor cell proliferation in a p53-independent manner. J Clin Invest 110: 1717-1727, 2002. 